\title{
When faith does violence: Reimagining engagement between churches and LGBTI groups on homophobia in Africa
}

\begin{tabular}{|c|c|}
\hline \multicolumn{2}{|c|}{$\begin{array}{l}\text { Authors: } \\
\text { Gerald West }{ }^{1} \\
\text { Charlene van der Walt }^{2} \\
\text { Kapya John Kaoma }^{3}\end{array}$} \\
\hline \multicolumn{2}{|c|}{$\begin{array}{l}\text { Affiliations: } \\
{ }^{1} \text { Old Testament and Biblical } \\
\text { Hermeneutics in the School } \\
\text { of Religion and Theology, } \\
\text { University of KwaZulu-Natal, } \\
\text { South Africa }\end{array}$} \\
\hline \multicolumn{2}{|c|}{$\begin{array}{l}\text { Department of Old and New } \\
\text { Testament, Stellenbosch } \\
\text { University, South Africa }\end{array}$} \\
\hline \multicolumn{2}{|c|}{$\begin{array}{l}{ }^{3} \text { Center for Global Christianity } \\
\text { and Mission, Boston } \\
\text { University, USA }\end{array}$} \\
\hline \multicolumn{2}{|c|}{$\begin{array}{l}\text { Corresponding author: } \\
\text { Gerald West, } \\
\text { west@ukzn.ac.za }\end{array}$} \\
\hline \multicolumn{2}{|c|}{$\begin{array}{l}\text { Dates: } \\
\text { Received: } 30 \text { May } 2016 \\
\text { Accepted: } 02 \text { Sept. } 2016 \\
\text { Published: } 24 \text { Nov. } 2016\end{array}$} \\
\hline \multicolumn{2}{|c|}{$\begin{array}{l}\text { How to cite this article: } \\
\text { West, G., Van der Walt, C. \& } \\
\text { Kapya, J.K., 2016, 'When faith } \\
\text { does violence: Reimagining } \\
\text { engagement between } \\
\text { churches and LGBTI groups } \\
\text { on homophobia in Africa', } \\
\text { HTS Teologiese Studies/ } \\
\text { Theological Studies 72(1), } \\
\text { a3511. http://dx.doi. } \\
\text { org/10.4102/hts.v72i1.3511 }\end{array}$} \\
\hline \multicolumn{2}{|c|}{$\begin{array}{l}\text { Copyright: } \\
\text { (C) 2016. The Authors } \\
\text { Licensee: AOSIS. This } \\
\text { is licensed under the } \\
\text { Creative Commons } \\
\text { Attribution License. }\end{array}$} \\
\hline \multicolumn{2}{|l|}{ Read online: } \\
\hline 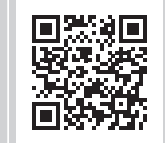 & $\begin{array}{l}\text { Scan this QR } \\
\text { code with your } \\
\text { smart phone or } \\
\text { mobile device } \\
\text { to read online. }\end{array}$ \\
\hline
\end{tabular}

'Homophobia' is shorthand for stigmatising attitudes and practices towards people who demonstrate sexual diversity. In this article, we reflect on how African Christian faith may become redemptive rather than violent in the context of lesbian, gay, bisexual, transgender and intersex forms of sexuality.

\section{Introduction}

This article offers reflection on work that has been done over the past decade or so in African contexts, across a number of continent-wide networks. Each of these networks has sought to construct safe and sacred places for dialogue with diversity, between African lesbian, gay, bisexual, transgender, intersex and queer (LGBTIQ) Christians, African theological educators and African church leadership. ${ }^{1}$

The emphasis of the article is on theological process rather than theological content. How we do theology resides at the centre of our current contestations around sexuality. Our starting point in terms of reimagining engagement between churches and LGBTIQ groups on homophobia in Africa is the actual real presence of LGBTIQ people. Without these people there can be no reimagining, there can only be violence. Diversity requires real diverse bodies. The theoretical movement traced within this article thus aligns strongly with the commitment and focus of liberation theology, namely, to start theological reflection from the position of the poor, marginalised and disenfranchised.

\section{An epistemological privilege}

Perhaps the most significant shift that we must imagine for the churches is for them to ground their theological work on LGBTIQ sexualities in the lived experience of LGBTIQ Christians. ${ }^{2}$ Doing theology from the perspective of and with marginalised sectors is not new. Liberation theologies have made such a commitment the starting point of the doing of theology. The epistemological privileging of particular marginalised experience is what characterises liberation theologies (Frostin 1988). ${ }^{3}$

The temptation and the tendency of what the South African Kairos Document (1985) (Kairos 1985) called 'Church Theology' is to impose pre-existing theology onto a new site of struggle. Sexuality has become a new site of struggle and the 'old' theology does not fit, for it is founded on heteropatriarchy. ${ }^{4}$ For sexuality in all its God-given fullness to become the subject of the doing of theology, marginalised sexual communities with their own particular experience must become the primary dialogue partners in the doing of theology. This does not mean that the long legacy of Christian theology is to be ignored; what it means is that this historically inherited theology must be interrogated for its usefulness for the new site of struggle.

Although the process of interrogating may be threatening to the establishment, it invites all God's people into a sacred process of knowing and understanding God's work in the contemporary

1.LGBTIQ is an umbrella term that aims to describe diversity in terms of sexual diversity and difference. Simply put, it is an initialism that stands for lesbian, gay, bisexual, transgender, intersex and queer. The term has various manifestations and is not exhaustive; rather, it aims at signifying complexity and diversity when it comes to issues of sexual diversity.

2.Given the focus of the workshop during which this paper was first presented, Homophobia \& the Churches in Africa: A Dialogue, the emphasis is on Christianity. However, our view is that interreligious and interfaith dialogue and collaboration are crucial.

3.The other characteristic elements of liberation theologies, as analysed by Per Frostin, are also instructive for the doing of queer theology (see West 2013, 2015).

4.'Heteropatriarchy' is a term that intersects the systems of oppression identified by feminist and gender scholars (namely, patriarchy and queer scholars), that is, heteronormativity. Heteronormativity refers to the understanding that heterosexual practice and desire is considered normal and anything deviating from this norm is somehow perverse, impossible or deviant. 
context, in which the churches are called to witness to God's involvement in the theological interrogation of the current oppressive situations in which sexual minorities exist.

Just as the Kairos Document was a 'challenge to church' (Kairos 1985, 1986), calling for repentance and conversion from 'Church Theology', so a prophetic and/or liberation theology of sexuality challenges the churches to repent from using the experience of heteropatriarchy as its primary dialogue partner. African church theologies are not neutral; they are heteropatriarchal. But privileging the experience of marginalised communities ought to be axiomatic for Christian theology. The God of Christianity is introduced in Exodus as the God who hears the cry of slaves (Ex 3:7). The biblical God is also the God who accompanies and leads the oppressed to the land of freedom, and who through the prophets protects God's people from both internal and external oppression. In God's fullest revelation, the Son of God is born on the margins of a colonised and marginalised people (Lk 2:1). It could and has been argued that within the shape of scripture God acts in specific social contexts, taking sides with the oppressed across historical time and geographical space, reminding us of the fact that marginalised communities are the springboard for Christian theology, ethics and ministry (Croatto 1987).

Framed in these ways, doing theology on sexuality requires that we grant an epistemological privilege to the lived reality of LGBTIQ Christians. We cannot do theology on sexuality without these realities. Putting it differently, rather than calling for the development of a new theology of sexuality and/or ties (an object to be produced), the call is for the development of a sexual theology appropriating as its starting point the embodied lived experiences of minority sexualities (a theological process). ${ }^{5}$

It must also be recognised that LGBTIQ Christians are already doing theology, often within their own bodies. And although such lived theology is not always clearly articulated, it is always present. This is what the Kairos Document referred to as 'people's theology' (Kairos 1986), and the task of 'prophetic theology' is for socially engaged biblical scholars and theologians to come collaboratively alongside people's theology and offer the biblical and theological resources required to construct a prophetic theology of sexuality (Nolan 1996).

From the above, it is clear that the churches' task is not to apply a ready-made theology to a contextual reality; the churches' task is to do theology with the contextual reality of lesbian, gay, bisexual, trans and/or intersexed (LGBTI) experience. The starting point for doing this new sexual theology is the lived experiences written on the bodies of LGTBIQ people.

5.Thatcher hints at this when discussing the four classic sources for doing theology namel, Scripture, tradition, reason and experience. Although experience has been included in this list, it has veasy seldom been appropriated as a relevant le legitimate source for doing theology. By calling for the development of sexua theology, the starting point for 'doing theology' changes to the lived embodied experience of LGTBIQ people themselves (Thatcher 2011:175-188).

\section{Affirming and articulating 'people's theology'}

Although a public 'prophetic' theology on sexuality is important, we as the church move too quickly if this becomes our focus. The process of creating a 'queer' (Cheng 2011) people's theology is a vital prerequisite. As the Kairos Document insisted, without people's theology there can be no prophetic theology. But people's theology is not simply a step on the way to the 'real' thing; people's theology is the real thing. It is the theology of the people in that it seeks to address the contradiction between the visible people and the invisible people. People's theology does not rest on definitions that reject 'other people' in favour of 'the people', but seeks to acknowledge the sacredness of all human beings, even those who are rendered invisible, as the image of the Creator.

Here is another of the churches' tendencies, to rush too quickly through what is a slow and complex process. The doing of LGBTIQ theologies requires a process that recognises the traumatised realities of LGBTIQ bodies. Traditional normative theologies of sexuality have traumatised queer Christians (Cvetkovich 2003). Only slow processes of trust and facilitation, in safe and sacred spaces, controlled by themselves (and their invited prophetic allies) ${ }^{6}$ can create the necessary conditions for the emergence of a queer people's theology (West 2011). In the context of the lived trauma experienced by LGTBIQ people within faith communities and because of religiously infused homophobia, the need for safe spaces where the voice of the oppressed can be heard cannot be overemphasised. Creating safe spaces for voice, words, song, ritual and the silence of solidarity to express the trauma experienced might assist in the reclaiming of agency and the development of a vocabulary of embodied resistance.

The doing of people's theology returns and affirms the biblical and the theological to LBGTIQ Christians, for whom the Bible and theology have usually been whips to chastise them. So while we may want to work with the centres of power within the churches, the task before us does not begin here. To focus

6.Michael White suggests that when people stand together in solidarity, however briefly and partially it' forbelieves that this makes it possible for people to 'think outside the limits of what we would otherwise think, to challenge aspects of our own participation in the reproduction of dominance, and to identify options for action in addressing disadvantage and inequality that would not otherwise be available to us' (White 1997:141). By creating a safe space where the voices of traumatised minorities are embraced within the safety of a caring community of allies, the possibility for 'compassionate witnessing' exists. Kaethe Weingarten describes the ideal witnessing position in relation to violence as one of 'awareness and empowerment' where we are able to acknowledge losses, to support mourning and grief, to humanise the enemy and to witness individual and collective pain with as much heartfelt compassion as we can muster (Weingarten 2003:21-38). Through 'compassionate witnessing' and a stance of solidarity, the possibility for 'reasonable hope' exists. 'Reasonable hope, consistent with the meaning of the modifier, suggests something both sensib, cand meaning of the modifier, suggests something both sensible and moderate, directing our attention to what is within reach more than what may be desired but unattainable. Reasonable hope softens the polarity between hope and despair, hope and hopelessness, and allows for (more) people to place themselves in the category of the hopeful ... Reasonable hope is relational; consists of practice, maintains that the future is open, uncertain and influenceable; seeks goals and pathways to them; and accommodates doubt, contradiction and despair' (Weingarten 2010:7-9).

7.Denise Ackerman hints at the value of genre of lament as follows:

I suggest that the ancient language of lament offers a vehicle for expressing the raw emotions ... The language of lament also offers the Body of Christ the opportunity to say: 'We are suffering, we stand in solidarity with all who suffer, we lament while we believe that there is hope for all in the Good news'. (Ackermann 2004:25) 
on the centre is to participate in the violence perpetrated by the centre. This is why organisations such as Inclusive and Affirming Ministries ${ }^{8}$ and the Pietermaritzburg Gay \& Lesbian Network $^{9}$ are so important. They already provide the safe and sequestered sites within which queer people's theology might be done. And we cannot make the move to a more public prophetic theology without affirming and building the theological capacity of queer Christians within such sites.

Such places are not apart from the church for they are part of the church. Such spaces provide the public theological witness of the rejection of God's people on one hand and the rethinking of the Christian faith and practice on the other hand. They testify to the fact that LGBTIQ Christians are not abstract beings, but people with sacred worth. It is in such sites that God raises up prophets (within the churches) to raise the theological and ethical consciousness of justice for the oppressed.

For it is from such sites that queer Christians must go out to take their rightful presence in the work of doing prophetic theology. But because the doing of prophetic theology requires engaging with the biblical and theological tradition, queer Christians must be thoroughly theologically equipped to re-encounter the very tradition that has tormented and traumatised them. This requires a biblical and theological interpretive resilience that can only be nurtured within a queer people's theology. 'Re-entering' the church to do theology is a potentially traumatic experience for LGBTIQ Christians who have often been driven out from their churches. Being biblically and theologically equipped for a 're-turn' to the church builds theological resilience, recovers the agency of queer Christians and affirms their dignity.

The “"Talking Back!" Think Tank: LGTBIQ Identities and Queer Perspectives' conference and workshop hosted at the Faculty of Theology, Stellenbosch University on May 2015 and resulting from the collaboration between the Beyers Naudé Centre for Public Theology at Stellenbosch University, Inclusive and Affirming Ministries and the Center for Christian Spirituality is a good example of initiatives that challenge the status quo of church engagement. The initiative aimed at bringing together, ecumenically, queer clergy in order to engage the direction of conversation within church structures. It has often been remarked that there are conversations on issues queer within the church, thus conversations 'about' LGTBIQ people, but very seldom conversations 'with' queer people. The aim of the event was to make a historical start in the process of determining the queer agenda within the church by giving voice to the embodied realities of LGTBIQ clergy and church leaders.

\section{The contested nature of the biblical and theological tradition}

Among the factors that would constitute biblical and theological interpretive resilience is a recognition that the

8.http://iam.org.za/

9.http://www.gaylesbian.org.za/
Bible' and 'Theology'10 are not singular things. Not only are they plural, but also they are inherently contested. The contestation is internal to the scriptural tradition. This is another area in which the churches are lacking; they imagine the Bible to have a singular message and their church theology to be applicable to each and every issue.

As other liberation theologies have begun to realise, a 'fundamentalism of the Left' (Assmann 1976) does not have the capacity, in the longer term (Mosala 1989), to liberate. And so there is no shortcut. The well-known texts of LGBTIQ terror must be carefully and critically engaged, as must other biblical (and all sacred) (Esack 1997; Esack \& Chiddy 2009; Jamal 2001; Palombo 2014) texts. The resources of queer biblical criticism offer a range of resources for this rereading task (Goss \& West 2000; Stone 2001). Difficult as it is for the churches to concentrate on the detail of scripture, prone as the churches are to theologically overdetermined interpretations of particular texts, the more difficult task is to assist the churches to recognise the contested nature of their sacred text (Brueggemann 1993). Feminist biblical studies and theology have prepared the ground for such a task; therefore, there is much to work with, but the very association of queer and feminist work compounds the problem for our churches.

However, creative work can be done often by coming at the question of the notion of a contested text obliquely, via a topic that is less contentious. For example, there are biblical texts that clearly condone slavery, but there are also biblical texts that reject and resist slavery. There is not one 'biblical' position on slavery. By working with the topic of slavery, as an example, the notion of a contested text can be explored more fully, leading into similar work on sexuality.

\section{My Bible and I}

And work with the Bible we must. The Bible must be a site of struggle in our African contexts. We cannot ignore or bracket the Bible, as has been the case in much 'western' Euro-American queer Christianity. This is why we also need to do our own African work on queer sexuality. We must engage the Bible, both the toxic texts and the Bible in general. Rereading the toxic so-called homosexuality texts demythologises them and enables queer Christianity to talk back to the Christian establishment (Lings 2013). Rereading these texts also offers other more redemptive interpretive options. For example, if Genesis 18-19 'really' is about hospitality and not homosexuality, then perhaps this text can be read for inclusion of and hospitality towards 'strange(r)' sexualities. At the very least, the text speaks to the role of protecting the stranger from the established culture of the time. Just as Abram (and later Lot) defended the stranger from abuse, he also negotiated the protection of the people of Sodom and Gomorrah. Regardless of where the church sees itself in that story, the need to stand with the vulnerable is critical to biblical interpretation and appropriation.

10.By 'theology', we include the full range of theological disciplines, including the ethical. 
However, if we are to move beyond homophobia, we must not allow the churches to determine which biblical texts are 'about' homosexuality. Biblical texts that speak to inclusion must be appropriated, as must, for example, the inclusive silence of Jesus on homosexuality. Homophobia in the churches inhabits a particular biblical shape, and so this biblical shape must be interrogated and destabilised and replaced with a redemptive and liberating shape. ${ }^{11}$ Rereading the 'prescribed' texts and offering redemptive readings of neglected texts are a part of this destabilising process. This can only be done if we 'take back the Word' (Goss \& West 2000), refusing to allow normative homophobic approaches to the Bible to dominate the interpretive terrain. Indeed, taking back the Word is in itself an empowering prophetic act. By reclaiming the biblical basis of our struggles, we re-experience God in new and diverse ways. We learn to re-experience God anew in the context of the cries of those oppressed because of their particular sexuality.

As important as rereading the Bible is in African contexts, this rereading must be corporate and collaborative rather than personal and individual. The dominant forms of African Christianity have become increasingly individualised. ${ }^{12}$ Residual forms of colonial Evangelical theologies have combined with the commodifying effects of globalisation to produce an array of individualised neo(colonial)-Evangelical, neo(colonial)Pentecostal, neo(colonial)-Charismatic African Christianities (Gifford 2008). By individualising sexuality theologically, LGBTIQ sexualities are made the responsibility of individual African Christians. By so doing, the sexual systems that construct LGBTIQ sexualities as abnormal and sinful are left unexamined.

Globalisation manufactures not only new forms of Christianity, but also shapes how African Christians respond to the plurality of perspectives generated by globalisation. On the one hand, globalisation constructs creative spaces in which LGBTIQ Christians can find solace and support (in cyberspace, for example) outside their own social systems. However, such spaces do not directly confront and deconstruct the dominant local systems. On the other hand, globalisation generates religio-cultural uncertainty within the dominant traditions, often leading to fundamentalist

\footnotetext{
11.For a discussion on 'the shape' of 'the gospel', see Nolan (1988).

12.Reiner Kessler's work on Intercultural Bible Reading is important in this regard. Rather than thinking of scriptural engagement as an individual/in-group endeavour, he calls for the shift to understating the reader in the Bible reading process as plural. Kessler describes the position of the reader in the Bible engagement process as:

These readers do not simply have the text as object of interpretation; they have other readers with whom they communicate. Reading the text thus becomes a other readers with whom they communicate. Reading the text thus becomes bipor mode And by means of the text, it is communication with the author. bipolar model. And by means of the text, it is communication with the author However, reading also includes communication with other readers. This communication forms a constitutive part of the process of understanding. Understanding the text is no longer possible without the communication with other readers. Through intercultural Bible reading, these other readers are no longer readers who come from the same context. These readers are different from one another and they are global. (Kessler 2004:457)

The 'reading with' approach brings together a diversity of voices and a range of interpretative tools. A 'queer reading with' approach will add to this the imperative of reading from the position of the oppressed.
}

assertions that traditional values are sacred and unchangeable, coercing local individuals to conform to 'the tradition' ${ }^{13}$

Unfortunately, African debates on sexuality are often 'captured' by individualising forms of Christian theology, whether it be the 'liberal' human rights ${ }^{14}$ orientation we have inherited from the Euro-American debates or the 'evangelical' personal moral orientation of African Christianities. Each in their own way asserts that their agenda for sexuality is universally applicable. Euro-American human rights advocates assume that their western-born agenda for sexual liberation is universally applicable. ${ }^{15}$ Thus, aside from forcing western forms of Queer activism on non-western cultures, this assumption undermines how sexuality is understood and studied on the continent (Amory 1997). We must not only take back the Word, we must also take back our African contexts/realities. ${ }^{16}$

To do African theology on sexuality, we must draw on other established African forms of biblical and theological hermeneutics, such as those found in inculturation, liberation, feminist/womanist, and postcolonial theologies (West 2010). These theologies offer communal and systemic perspectives and resources for doing queer theology. Each of these overlapping and intersecting ${ }^{17}$ theologies seeks to interrogate the Christian faith from the perspective of the oppressed as opposed to the powerful. Though often uncomfortable for the churches, they allow us to theologise and ethicise in ways that open us to divine surprises within the faith community and the world.

However, in drawing from these African theologies we must also recognise their limits. Each of these has found it difficult to transgress the boundary of 'decent' theology. They have restricted themselves to doing 'decent' theology, baulking at God's call to venture, with Jesus and the sex workers of his day, ${ }^{18}$ into doing 'indecent theology' (Althaus-Reid 2000). ${ }^{19}$

\section{Intersecting systems}

By drawing on African theologies that focus on social systems (including religio-cultural systems), queer African theology can begin to interrogate the systems that render LGBTIQ sexualities as abnormal and abhorrent, as un-African, demonic and evil, thus robbing them of their humanity. Heteropatriarchy is clearly one of the religio-cultural and socio-political systems that undergird homophobia.

13.The effects of globalisation on religion deserve more careful attention ssee, e.g. Stålsett (2006)].

14.African articulations of 'human rights' discourse are potentially more useful, (see http://www.achpr.org/)

15.For a similar argument with respect to feminism, see Mahmood (2005).

16.For example, at the workshop, 'Homophobia \& the Churches in Africa: A Dialogue' (7-8 April 2016), at which an earlier version of this article was presented, one of the participants suggested that it would be more contextually appropriate to rewrite 'LGBTI' as 'ITLGB', as intersexuality and transsexuality were more 'recognisable' in African contexts.

17.For an exploration of a range of intersections, see Punt (2011).

18.For a detailed work on reading the Bible with sex workers, see Ipsen (2009) and also Kaoma (2015).

19.'The queer God' (2003) Althaus-Reid summons us to examine the dialectics of decency and indecency by exploring the relevance of sexuality, in general, and sexual stories from the margin, in particular, for doing theology. Althaus-Reid employs insights from liberation theology, queer theory, post-Marxism and postcolonial analysis to explore the above-mentioned landscape. 
'Corrective rape', ${ }^{20}$ whether of gay men or lesbian women, is a sign of patriarchy's pathology, as it battles (literally) to bring 'unruly' African bodies back into their normative place within patriarchy, disciplining them. Heteropatriachy's desire to control African bodies takes many forms, including the criminalisation of gay and lesbian sexualities by African nation states. By branding LGBTIQ sexualities as socially deviant and religiously demonic, African governments and African churches absolve themselves of dialogue with queer communities. Worse, during times of crisis or elections, homophobia is wheeled out by African politicians (and taken up by church leaders) in attempts to deflect from socioeconomic matters (Gunda 2010), fuelling homophobia.

Furthermore, by branding LGBTIQ Christians as inherently evil, another dimension is added to the theological task. African Christianities, even those with Evangelical leanings, have been able to reject slavery because they were rejecting an evil system. But all forms of African Christianity, including Africa's liberation theologies, have found it difficult, theologically, to do indecent theology, precisely because LGBTI people have been declared to be inherently deviant (un-African) and evil (sinners) (Garner \& Worsnip 2001).

The Elmina Statement (Consultation 2015), produced through a dialogical process between LGBTI Christians, church leaders, theological educators and activists, is a good example of doing African theology on sexuality outside the personal paradigm. Adopting a systemic approach to sexuality, recognising the affinities between the system of slavery and the system of homophobia - recognising, for example, that both are constructed on the desire to control the bodies of denigrated others - shifts the theological discourse in ways that African pastors and priests have found useful. Queer sexuality becomes a matter of social justice not personal morality, and this resonates with Africans who have such a long history of systemic injustice.

To critically and proactively engage contextual expressions of homophobia, the importance of intersectional ${ }^{21}$ thinking cannot be ignored. When negotiating embodied identity and negating the heteronormative insistence on 'correction' through culture-validated violence, the multiple intersecting axes of oppression need to be taken into consideration. When considering and engaging the embodied realities of, for

20. South Africa is also considered to be the birth place of the so-called "'corrective rape": an act of violence against women committed by men ostensibly to "cure" lesbians of their nioncon that homosexuality is an imported white disease (from the colonial empire) (Di Silvio 2010:1470). It is especially African women and girls thought to be lesbian who become victims of corrective rape, with the claimed purpose of turning them into 'real African women'. 'Attackers, often family members, friends, or neighbors of the victims, say they are teaching lesbian women "a lesson" by raping them and 'showing them how to be "a real woman"' (Di Silvio 2010:1471). Although black lesbians are the main targets of corrective rape, any woman with a nonconforming sexual identity is at risk, seeing that the aim or goal is to 'cure' or 'discipline' or punish any nonconforming sexual orientations. Thus, any woman thought to be too different or insufficiently feminine and who fails to stay invisible is at risk. Accordingly $86 \%$ of black lesbians from the Western Cape said they lived in fear of sexual assault' (Di Silvio 2010:1471). This kind of contextual positioning is what was referring to earlier in the paper and think should introduction, footnote to the introduction or section grounding the challenges ...

21.Maneesha Deckha alludes to academic reflection termed as intersectional when explaining the aim as follows: 'theoretical commitment to recognizing how multiple axes of differences coalesce to shape human experiences of injustice (Deckha $2008: 249$ ). example, black lesbian women within the South African township context, the constellation of factors represented in axes of identity, such as race, class, gender, sexuality and socio-economic realities, need to be engaged at the complex point of intersection (Deckha 2008).

Analysing Africa's (intersecting) sexual systems is therefore vital. And to do this thoroughly will require disaggregating 'L-G-B-T-I', for these are not the same, with each inhabiting different yet overlapping sexual systems. Politically, the aggregated designation 'LGBTI' is important; existentially, each sexual identity demands its own reality and its own theological work.

\section{Embodied resistance}

Central to much of the argument above for a faith that moves beyond homophobic violence is the insistence on the reclaiming of the body in the process of doing theology and the appropriation of the body as a site of revelation. In terms of LGTBIQ people, the church context has often been a painfully reductionist reality as unidirectional discussions around sexual practice and conduct have often dominated conversations engaging the interface between faith and minority sexualities (Misibi 2013). The predominant tone in these engagements has been a moralising emphasis on what the body 'should $\mathrm{do}^{\prime 2}{ }^{22}$ The so-called Bible-based heteronormativity dictates (rather than dialogues about) what is 'natural' or 'normal' in terms of sexual conduct, and 'the other' in terms of this norm will often be stigmatised as hypersexual and/or promiscuous or deviant. ${ }^{23}$

If we are to move beyond homophobia, we must, we argue, push back against this normative proclamation of what a body 'should do' and rather ask the performative question 'what can a body do?' (Butler 1999). By shifting the emphasis from normative to performative, we make space for more bodies to matter and for the inclusion of the embodied lived experience of LGTBIQ bodies. ${ }^{24}$ Drawing on queer theory in doing queer theology, ${ }^{25}$ we can move towards these goals by engaging in critical reflection on heteronormativity and the dehumanisation that it has engendered by the development of a vocabulary for gay or queer people to speak about their experiences of sexuality, and by the development and promotion of counter-narratives to the dominant.

22.Jean Comaroff's engagement with heteronormativity in the context of HIV and AIDS in Africa is pertinent: 'Across Africa ... discourses of prevention and shame have been common [...]. The spread of Aids has spurred the vilification of homosexuality [...]. It has also licensed the policing of other forms of sexuality not securely under control of normative authority, hence the demonization of independent women, immigrants, and youth' (Comaroff 2007:197).

23.Gust Yep describes this process as follows:

The process of normalization of heterosexuality in our social system actively and methodically subordinates, disempowers, denies and rejects individuals who do not conform to the heterosexual mandate by criminalizing them, denying them protection against discrimination, refusing them basic rights and recognition, or all of the above. (Yep 2003:24)

24.Although liberating, this space becomes theoretically contested as identity politics intersects with the queer agenda. Queer theory calls for the move beyond the intersects with the queer agenda. Queer theory calls for the move beyond the
confines of identity politics, resists any form of dominant/normal construction, to the radical politics of inclusion.

25.Patrick Cheng describes queer theology as consisting of the following:

First, queer theology is LGBT people 'talking about God'. Second, queer theology is 'talking about God' in a self-consciously transgressive manner, especially in terms of challenging societal norms about sexuality and gender. Third, queer terms of challenging societal norms about sexuality and gender. Third, queer
theology is 'talk about God' that challenges and deconstructs the natural binary categories of sexual and gender identity. (Cheng 2011:9) 
When risking the endeavour of finding a vocabulary to give voice to our embodied experience and name our vulnerabilities, new imaginings of solidarity and community are made possible (Butler 1999; Nussbaum 1999). This human condition of interdependence and vulnerability should be the basis of reimagining - instead of destroying - the possibility of community. The possibilities of crossing boundaries and standing in solidarity with the other, when discovering our communal vulnerability, are made poignantly visible in the 2014 film Pride, when young LGTBIQ activists from London stand in solidarity with a small mining community in Wales during the lengthy strike of the National Union of Mineworkers in the summer of 1984.

The film reminds us of the importance of the physical presence of bodies (Butler 2006; Scott 1990). Speech is not always possible, and so bodily presence must be recognised as a performative 'utterance'. Assemblies of physical bodies have an expressive dimension that cannot be reduced to speech, for the very fact of people gathering together 'says' something without always relying on speech.

Textures of these theoretical insights can be traced through the decision-making process of the landmark 2015 General Synod of the Dutch Reformed Church in South Africa regarding the ordination of LGTBIQ clergy and the possibility of blessing same-sex unions. ${ }^{26}$ The positive outcome of the synod marked a historical first for mainline Christian denominations on the African continent. The conditions and processes that gave rise to the decision have been described by some as a 'perfect storm'. Although no exhaustive engagement with the process can be offered here, the role played by the silent embodied resistance of gay clergy at the General Synod meeting as well as the stance of solidarity taken by many when speaking on behalf of the voiceless played no small part in this historical decision. Those who are so often spoken about in church context were visibly present, an embodied reminder that our words often create realities for those who are invisible.

The importance of embodied resistance as an attempt to create a space for 'more bodies to matter' within Bible-based heteronormative institutions continues to stay high on the queer agenda, especially considering the severe backlash against the inclusionary nature of the Dutch Reformed Church (DRC) decision. The often voiceless embodied challenge to faith communities remains one of moving from mere friendly communities (that tolerate diversity) to inclusive communities who celebrate, claim and insist on diversity.

\section{The pastoral threshold}

While in this article we have made an argument for a theological process shaped by the presence and epistemologies of LGBTIQ people, we recognise that we also need strategic resources for those who are not yet ready to embrace this theological process.

26.For more comprehensive analysis of the Dutch Reformed Church's process regarding same-sex relationships, see van der Walt (2016) and van Loggerenberg (2015).
The long, slow, dialogical processes (Consultation 2016) that enabled the production of the Elmina Statement are important in facilitating the redoing of African theology on sexuality. By dialoguing diversity rather than debating diversity, by creating a critical mass of queer Christians, by carefully identifying church leaders who were willing to listen, by making Bible study part of the fabric of the encounter, by being attentive to the see-judge-act process, by locating the workshops within a prophetic liturgical infrastructure, change took place.

However, change at the institutional level is slow and fragile, and so homophobia remains a daily reality for African LGBTI Christians. In the shadow of the Elmina castle in Ghana, we agreed that the single most important resource for the churches is a pastoral counselling manual that would equip pastors and priests to meet a minimal pastoral threshold when confronted by homophobia, particularly 'protective homophobia' - that is, organised opposition to homosexuality as an attempt to protect Africa's traditional heritage, religion and children from the imperial homosexual agenda.

What would be the African Christian minimum pastoral requirement when asked for protection and support from a gay or lesbian Christian (or their families and friends), even if that pastor did not 'accept' homosexuality? The current context in which we find ourselves is a 'kairos' or 'Esther' moment. Not only will a failure of this 'minimal pastoral requirement' push sexual minorities from the church, it will also force them to find support from various 'global' sources, for example, the web. The result will be a less human and a less godly African church.

By constructing theological resources that facilitate and enable a minimal pastoral response that is life-affirming and dignity-granting for queer Christians, African churches will have some minimal capacity for theological change. Fortunately, Jesus reminds us in the parable of the mustard seed that the beginnings of redemptive faith need only be small (Mark 4:30-32).

\section{Issues for further consideration}

Among the other matters that matter in moving the churches beyond homophobic forms of faith are establishing alliances with those of other faiths, including specifically African Islam and African (Traditional) Religion. Each of these faith traditions, like Christianity, is contested, and so is being summoned by LGBTIQ people of faith to offer affirming theologies. The contemporary reality is that these faiths are in an unholy alliance, fuelling each other's homophobia and feeding the flames of violence.

Traditional theological trajectories such as 'creation theology', while offering affirming and inclusive theological resources, must be re-envisaged. How do we affirm the dignity of each and every human being as made in the image and likeness of God without demanding that they procreate? From Anglicans to Pentecostals to Roman Catholics to Muslims, the 
assumption is that sex is for procreation. Because sexual minorities are assumed not to procreate, their sexual expression is presumed to be against God's original plan in creation. It is within this context that African sexual politics exists. In this regard, there is a need for exploring an African theology and ethics of sex (and not only sexuality).

No matter what other matters are added to the discussion, provided that sexual 'others' really do matter, African churches have the theological resources necessary to move beyond homophobia. This paper emphasises theological process rather than theological content. 'Doing theology' in ways that include LGBTIQ Christians who have been othered, objectified and vilified as subjects is vital for the African churches if they need to move beyond a faith that does violence.

Finally, given that religio-cultural change is slow, it is important for LBGTIQ Christians and their families and allies to lobby for legal change in African nation states. While African churches hesitate to protect their own people, LGBTIQ Christians, we must advocate for the state to take up this task. Legal state protection in South Africa, for example, has made a difference in LGBTIQ life, even if religio-cultural patriarchy considers the South African Constitution as undermining its rule (Burchardt 2013).

\section{Acknowledgements Competing interests}

The authors declare that they have no financial or personal relationships which may have inappropriately influenced them in writing this article.

\section{Authors' contributions}

The publication developed as conditioned research by The Other Foundation for a consultation on The Church and Homophobia. G.W. provided the conceptual framework for the paper and the writing was done collaboratively by G.W., C.v.d.W. and K.K., G.W. and C.v.d.W. took responsibility for the editing of the texts.

\section{References}

Ackermann, D.M., 2004, 'Tamar's cry: Re-reading an ancient text in the midst of an HIV and AIDS pandemic', in M.W. Dube \& M.R.A. Kanyoro (eds.), Grant me justice! HIV/AIDS \& gender readings of the Bible, pp. 27-59, Cluster Publications, HIV/AIDS \& gender
Pietermaritzburg.

Althaus-Reid, M., 2000, Indecent theology: Theological perversions in sex, gender and politics, Routledge, London.

Althaus-Reid, M., 2003, The queer God, Routledge, London.

Amory, D.P., 1997, 'Homosexuality in Africa: Issues and debates', A Journal of Opinion 25(1), 5-10. http://dx.doi.org/10.2307/1166238

Assmann, H., 1976, Theology for a nomad church, Orbis, Maryknoll, NY.

Brueggemann, W., 1993, 'Trajectories in Old Testament literature and the sociology of ancient Israel', in N.K. Gottwald \& R.A. Horsley (eds.), The Bible and liberation: Political and social hermeneutics, pp. 201-226, Orbis, Maryknoll, NY.

Burchardt, M., 2013, 'Equals before the law? Public religion and queer activism in the age of judicial politics in South Africa', Journal of Religion in Africa 43, 237-260. http://dx.doi.org/10.1163/15700666-12341258

Butler, J., 1999, Gender trouble: Feminism and the subversion of identity 10th anniversary edition, Routledge, New York.

Butler, J., 2006, Precarious life: The powers of mourning and violence, Verso, London.
Cheng, P.S., 2011, Radical love: An introduction to queer theology, Seabury Books, New York.

Comaroff, J., 2007, 'Beyond bare life: AIDS, (bio) politics, and the neoliberal order', Public Culture 19(1), 197. http://dx.doi.org/10.1215/08992363-2006-030

Consultation, Sexuality, 2015, Elmina statement, viewed 8 March 2016, from http:// www.chicagoconsultation. $\mathrm{org} / \mathrm{p} \mathrm{p}=250$

Consultation, Sexuality, 2016, 'Elmina Consultation statement (2015)', in E. Chitando \& A. Van Klinken, Christianity and controversies over homosexuality in Africa, pp. 199-200, Routledge, London.

Croatto, J.S., 1987, Biblical hermeneutics: Toward a theory of reading as the production of meaning, Orbis, New York.

Cvetkovich, A., 2003, An archive of feelings: Trauma, sexuality, and lesbian public cultures, vol. 308, Duke University Press, Durham, NC.

Deckha, M., 2008, 'Intersectionality and posthumanist visions of equality', Wisconsin Journal of Law Gender and Society 23(2), 249-267.

Di Silvio, L., 2010, 'Correcting corrective rape: Carmichele and developing South Africa's affirmative obligations to prevent violence against women', Georgetown Law Journal 99, 1469-1515.

Esack, F., 1997, Qur'an, liberation and pluralism: An Islamic perspective of interreligious solidarity against oppression, OneWorld, Oxford.

Esack, F. \& Chiddy, S. (eds.), 2009, Islam and AIDS: Between scorn, pity and justice, Oneworld, Oxford.

Frostin, P., 1988, Liberation theology in Tanzania and South Africa: A First World interpretation, Lund University Press, Lund.

Garner, H. \& Worsnip, M., 2001, 'Oil and water: The impossibility of gay and lesbian identity within the church', in M. Speckman \& L.T. Kaufmann (eds.), Towards an agenda for contextual theology: Essays in honour of Albert Nolan, pp. 205-230, agenda for contextual theology: Essays in
Cluster Publications, Pietermaritzburg.

Gifford, P., 2008, 'The Bible in Africa: A novel usage in Africa's new churches', Bulletin of SOAS 71(2), 203-219. http://dx.doi.org/10.1017/s0041977x08000505

Goss, R.E. \& West, M. (eds.), 2000, Take back The Word: A queer reading of the Bible, The Pilgrim Press, Cleveland, $\mathrm{OH}$.

Gunda, M.R., 2010, The Bible and homosexuality in Zimbabwe: A socio-historical analysis of the political, cultural and Christian arguments in the homosexual public debate with special reference to the use of the Bible, University of Bamberg Press, Bamberg.

Hornsby, T.J. \& Stone, K.A. (eds.), 2011, Bible trouble: Queer reading at the boundaries of biblical scholarship, Society of Biblical Literature, Atlanta, GA.

Ipsen, A., 2009, Sex working and the Bible, Equinox, London.

Jamal, A., 2001, 'The story of Lot and the Qur'an's perception of the morality of samesex sexuality', Journal of Homosexuality 41(1), 1-88. http://dx.doi.org/10.1300/ J082v41n01_01

Kairos, 1985, Challenge to the church: The Kairos document: A theological comment on the political crisis in South Africa, The Kairos Theologians, Braamfontein.

Kairos, 1986, The Kairos document: Challenge to the church: A theological comment on the political crisis in South Africa, Rev. 2nd edn., Skotaville, Braamfontein.

Kaoma, J.K., 2015, 'Beyond Adam and Eve: Jesus, sexual minorities and sexual politics in the church in Africa', Journal of Theology for Southern Africa 153, 6-27.

Kessler, R., 2004, 'From bipolar to multipolar understanding: Hermeneutical consequences of intercultural Bible reading', in H. de Wit, L.C. Jonker, M. Kool \& D. Schipani (eds.), Through the eyes of another: Intercultural reading of the Bible, pp. 452-459, Institute for Mennonite Studies, Elkart.

Lings, K.R., 2013, Love lost in translation: Homosexuality and the Bible, Trafford Publishing, Bloomington, IL.

Mahmood, S., 2005, The politics of piety: The Islamic revival and the feminist subject, Princeton University Press, Princeton, NJ.

Misibi, T., 2013, 'Denied love: Same-sex desire, agency and social oppression among African men who engage in same-sex relations', Agenda 27(2), 105-116.

Mosala, I.J., 1989, Biblical hermeneutics and black theology in South Africa, Eerdmans, Grand Rapids, MI.

Nolan, A., 1988, God in South Africa: The challenge of the Gospel, David Philip, Cape Town.

Nolan, A., 1996, 'Work, the Bible, workers, and theologians: Elements of a workers' theology', Semeia 73, 213-220.

Nussbaum, M.C., 1999, Sex and social justice, Oxford University Press, Oxford.

Palombo, M.C., 2014, 'Interfaith praxis in South African struggle for liberation: Toward a liberatio-political framework for Muslim-Christian relations', PhD, Semitic Languages and Cultures, University of Johannesburg.

Punt, J., 2011, 'Queer theory, postcolonial theory, and biblical interpretation', in T.J. Hornsby \& K. Stone (eds.), Bible trouble: Queer reading at the boundaries of biblical scholarship, pp. 321-341, Society of Biblical Literature, Atlanta, GA.

Scott, J.C., 1990, Domination and the arts of resistance: Hidden transcripts, Yale University Press, New Haven, CT.

Stålsett, S.J., 2006, Spirits of globalization: The growth of Pentecostalism and experiential spiritualities in a global age, SCM Press, London.

Stone, K. (ed.), 2001, Queer commentary and the Hebrew Bible, The Pilgrim Press, Cleveland, $\mathrm{OH}$.

Thatcher, A., 2011, God, sex, and gender: An introduction, John Wiley \& Sons, Chester. 
Van der Walt, C., 2016, "Is "being right" more important than "being together"? Intercultural Bible reading and life-giving dialogue on homosexuality in the Dutch
Reformed Church, South Africa', in E. Chitando \& A. Van Klinken (eds.), Christianity and controversies over homosexuality in contemporary Africa, pp. 125-137, and controversies
Routledge, Oxford.

Van Loggerenberg, M., 2015, 'The 2007 Dutch Reformed Church Synod resolution: Impact on gay ministers', HTS Teologiese Studies/Theological Studies 71(3), 1-9. http://dx.doi.org/10.4102/hts.v71i3.2894

Weingarten, K., 2003, Common shock. Witnessing violence every day. How we are harmed, and how we can heal, Dutton, New York.

Weingarten, K., 2010, 'Reasonable hope: Construct, clinical applications and supports', Family Process 49(1), 5-25. http://dx.doi.org/10.1111/j.1545-5300.2010.01305.x

West, G.O., 2010, 'Biblical hermeneutics in Africa', in D.B. Stinton (ed.), African theology on the way: Current conversations, pp. 21-31, SPCK, London.
West, G.O., 2011, 'Newsprint theology: Bible in the context of HIV and AIDS', in J. Havea \& C. Pearson (eds.), Out of place: Doing theology on the crosscultural brink, pp. 161-186, Equinox Publishing, London.

West, G.O., 2013, 'Liberation hermeneutics', in S.L. McKenzie (ed.), The Oxford encyclopedia of biblical interpretation, pp. 507-515, Oxford University Press, Oxford

West, G.O., 2015, 'Africa's liberation theologies: An historical-hermeneutical analysis', in S.D. Brunn (ed.), The changing world religion map: Sacred places, identities, practices and politics, pp. 1971-1985, Springer, Dordrecht

White, M., 1997, Narratives of therapists' lives, Dulwich Centre Publications, Adelaide.

Yep, G.A., 2003, 'The violence of heteronormativity in communication studies: Notes on injury, healing, and queer world-making', in G.A. Yep, K.E. Lovaas \& J.P. Elia (eds.), Queer theory and communications. From disciplining queers to queering the discipline(s), pp. 11-60, Harrington Park Press, New York. 